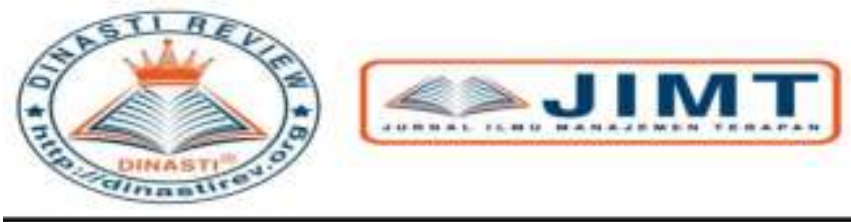

+62 878-9658-6407

087896586407

https://dinastirev.org/JIMT editor@dinastirev.org

\title{
SELFIE MARKETING AND CUSTOMER LOYALTY: MEDIATING ROLE OF EXPERIENTIAL SHOPPING
}

\section{1) Ade Octavia, ${ }^{2)}$ Yayuk Sriayudha}

${ }^{1)}$ Lecturer of Faculty Economic and Business, Universitas Jambi, Indonesia

${ }^{2)}$ Lecturer of Faculty Economic and Business, Universitas Jambi, Indonesia

\begin{tabular}{|c|l|}
\hline $\begin{array}{c}\text { ARTICLE INFORMATION } \\
\text { Received: } 11 / 01 / 2020 \\
\text { Revised: } 21 / 01 / 2020 \\
\text { Issued: 07/02/2020 } \\
\text { (filled in by Editor) }\end{array}$ & $\begin{array}{l}\text { Abstract: The increasing growth of modern food stalls } \\
\text { showed a change in the behavior of consumers, } \\
\text { especially for teenagers to fulfill the needs of a } \\
\text { representative place to increase social activity. The } \\
\text { purpose of this study is to analyze the effect of selfie } \\
\text { marketing and customer loyalty with experiential } \\
\text { shopping as a mediating role. The authors seek to } \\
\text { understand how this selfie marketing to determine the } \\
\text { customer loyalty of modern food stalls customer through } \\
\text { experiential shopping. Design research using } \\
\text { Email: } \\
\text { quantitative methods with the approach of the survey. } \\
\text { Sample consumer research is the modern method of } \\
\text { stalls that add up to 150 people. Sampling method using } \\
\text { yayuksriayudha@gmail.com } \\
\text { judgement sampling. The tools of data analysis using the } \\
\text { method PLS. Finding suggests that experiential } \\
\text { shopping has a significant effect on selfie marketing and } \\
\text { experiential shopping and selfie marketing affects } \\
\text { customer loyalty on modern food stalls. } \\
\text { Keywords: Customer Loyalty, Experiential Shopping, } \\
\text { Selfie Marketing }\end{array}$ \\
DOI:10.31933/JIMT
\end{tabular}

\section{INTRODUCTION}

Modern food stalls are now widely found in big cities that offer a relatively affordable menu with a unique, modern and comfortable concept. Consumers come to modern food stalls not only because of the desire to eat and drink but the need to socialize with colleagues, friends, and family. In recent years, a number of theme restaurants have established in many countries in the world. Keen competition exists for this type of restaurants. Heung (2007) observed that customers who visit this type of modern restaurant seem not only to enjoy their food but also to enjoy their environment. Little is known about what customers expect and how they select this type of modern restaurant. The increasing growth of modern stalls in the city of Jambi showed that a change in the behavior of consumers, especially the millennium generation in meeting the needs of representative places to increase their social activities. The experience gained through this socialization activity becomes very important when information can be shared to various social media so that it becomes the consumption of many people. Experiential is an approach to provide information that is more than just information about a product or service by creating a holistic experience for consumers 
(Brown and Albright, 2013; Lang and Hooker, 2013).

Customer experience is also acknowledged as a dominant objective for organizational strategy, affecting sustainable differentiation from competition. Customer experiences do not only differentiate the company from its competitors but also create loyal customers that spread positive word of mouth The main focus of an experiential is on the five senses, influences, actions and relationships. The five senses that are the entrance to person must be stimulated correctly. Experiences are memorable (Pine \& Gilmore,1999; Cetin et al 2014 ). Similarly one can analyze the characteristics of a product from three different perspectives (1) the technical characteristics are those about the physical product (2) service characteristics and experience characteristics are about what is sensed and remembered (3) shared characteristic of a positive customer experience is that it is unique, distinct from regular, memorable, and positive word of mouth

The development of social media is inseparable from the development of smart phones. By the end of 2014, the development of smart phone customers had increased by $20 \%$ with the most rapid developments in China, India, Indonesia, Brazil and Russia which were estimated to make 93 million selfie every day (Gartner in Senft and Baym, 2015). The phenomenon of selfie is now the latest topic for marketers so that they can contribute to the market. Marketers who understand consumer behavior can create effective marketing strategies and can maintain business continuity in the long term (Author, 2017). Everyone has the chance to talk freely about anything they like. Also it is filled with frames of life so brand awareness activities carried out through social mediums seem more sincere.

Kotler and Keller (2011) reported that customer loyalty does not form in a short period of time but through the learning process and based on the results of the consumer's own experience of purchasing is consistent all the time. Just a touch of real life. Social media is considered as a digital media with a high potential for marketing activities and get attention from consumers. Social media is freedom, sincerity, entertainment and low costs (Cizmerci and Ercan, 2015). The quality and range or type of modern food stall are key determinants in consumer loyalty, but that the concept of quality of food offers a range of interpretations and thus requires more careful investigation. Additionally, the concept of the "meal experience" as a holistic abstraction in the consumer's mind is called into question as a consequence of the analysis (Clark and Wood, 2009). Tangible rather than intangible factors are identified as being of greater importance in consumer loyalty.

Bowden (2009) researched that customer satisfaction paradigm as the most effective method with which to evaluate service experiences at the expense of other relational mediators such as involvement, calculative commitment, affective commitment, and trust. A phenomenological investigation into the process of customer engagement, as revealed through customers' restaurant dining experience. Kim and Stepchenkova (2017) found that positive emotions are affected by the escapism and customer ROI dimensions of the experiential value but not by atmosphere or service excellence dimensions of the modern restaurant. While this result might seem counter-intuitive toward our research. Indonesian customers tend to perceive modern restaurants of Western brands as more upscale restaurants compared to traditional Indonesia restaurants This researched is try to explaining customer loyalty with mediating role of experience shopping for customer of modern food stalls and restaurant. 


\section{LITERATURE REVIEW}

\section{Selfie Marketing}

The Oxford Dictionary officially defines the selfie as a photograph that one has taken of oneself, usually with a webcam or smart phone. The concept of a selfie is simple: a consumer takes a photo or video of himself or herself, shares it through social media and, then, waits for feedback (Fox et al, 2018). Iqani and Schroeder (2015) observed that Selfie invoke important issues in communication, photography, psychology, self-expression, and digital media studies - as they bring up a host of concerns about identity, privacy, security, and surveillance. Weichan and Yang (2016) reviewed that selfie behavior is related to self-respecting behavior (narcissism) and certain individual attitudes in doing selfie also determine the typeof indicator for each person's personality and the implications available to marketers. The selfie effect is a catalyst for commercial pressure (Berg, 2017). The overt meaning of sharing selfie is to connect socially, confirming friendship. Fox et al (2018) investigated many informants emphasized precisely how customer preferences were influenced by those of their peers or colleague rather than ads.

Assumptions about selfie marketing still require empirical data that supports before marketer corporate selfish behavior and consider that it is part of the marketing plan. Wall Street Journal (2014) argued that many companies have developed software to detect selfie behavior as part of marketing data, which is expected to find emotion. consumer. Furthermore, the phenomenon of self is now the latest topic for marketers so that it can contribute to marketers and customers themselves.

Hypothesis 1a : Experiential shopping has a significant effect on selfie marketing.

Hypothesis 1b: The dominant experiential shopping variable influencing selfie marketing variables is store décor.

\section{Experiential Shopping}

Schmitt (1999) observed that experience-oriented marketers view consumers both rationally and emotionally as focusing on achieving a pleasant experience. Schmitt further said that the experiential concept is increasingly being used by companies to create experiential connections with their customers. This concept is especially relevant for multinational companies to encourage the formation of global brands. Experiential shopping can be used profitably in many situations including 1 . Re-creating a brand that has decreased 2. Differentiating a product from its competitors 3. Creating an image and identity for company 4. Promoting innovation 5. Encouraging trial and purchase most important consumption. Sharma (2011) reviewed that experiential is interpreted as the subject of change in each individual who emphasizes emotions and the five senses when the dimensional process acquires knowledge. The marketing, on the other hand, provides a more objective experience because it expresses ideas that are significantly directly enjoyed based on perceived experience. In its development, marketing management science uses the experience as one of the variables.

Store atmosphere is increasingly becoming an area of interest in Marketing studies . Furthermore, Lang and Hooker (2013) observed that consumer behavior arises from consumer thinking, feelings and responses when shopping. The end result of this shopping behavior is consumer desires and business consequences such as consumption patterns, satisfaction, loyalty, sales, and profits. It became essential to build an environment that can 
create a unique customer experiences, creating the link between an experiential view of consumption and the traditional approach to decision making (Farias et al., 2014). The focus of experiential marketing concept on holistic and eclectic experiences that enhance customer's hedonic consumption. Indeed, this tactic can influence customer within the store shopping behavior due to its multi-sensory aspects, not only accordingly to the number and type of cues, but also based on their combined effect, creating an overall positive impression on consumers in the store.

Hypothesis 2: Variable selfie marketing has a significant effect on consumer loyalty.

\section{Customer Loyalty}

Maintaining customers is the same as maintaining the survival of the company so that it can increase loyalty. Further indicators of customer loyalty are repeat purchase which is loyalty to product purchases, retention which is resilience to negative influences regarding the company and referrals which is referring to the total firmness of the company ( Kotler \& Keller, 2011). Consumer loyalty is not formed in a short time but through the learning process and based on the results of the experience of the consumers themselves from consistent purchases over time. If what is already in line with expectations, then the purchase process continues to repeat. It can be said that consumer loyalty has arisen. If from his experience, the consumer does not get a satisfying brand then he will not stop to try other brands until he gets the product or service that meets the criteria. They managed to find that the quality of connectedness which consists of satisfaction, trust and commitment has a positive relationship with loyalty. Customers who are satisfied and loyal (loyal) are an opportunity to get new customers. Maintaining all existing customers will generally be more profitable than customer changes because the cost of attracting new customers can be five times the cost of maintaining an existing customer.

Hypothesis 3 : Experiential shopping and selfie marketing affect consumer loyalty

\section{Research Model}

The authors propose a model that describes the relationship between experiential shopping, selfie marketing and customer loyalty (See Figure 1). . In conclusion, the results are discussed along with the theoretical and managerial implications of the findings.

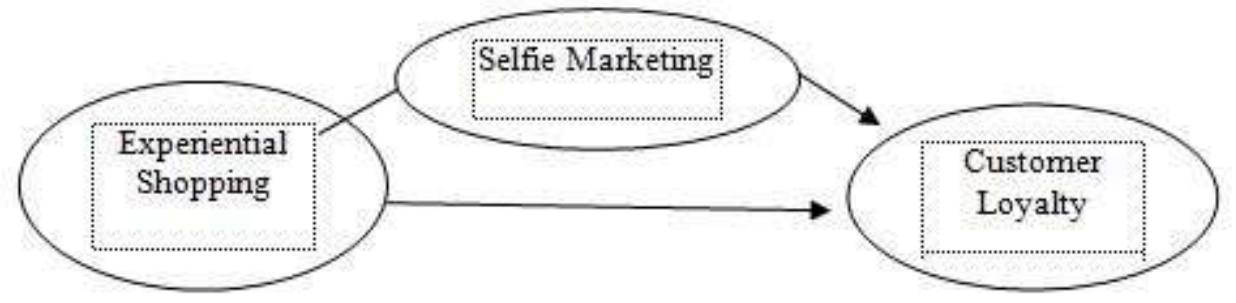

Figure 1. Research Model

\section{METHODS}

This research is descriptive quantitative research with a sample survey approach and observation. The survey approach is used to measure existing symptoms and help to compare with predetermined criteria. The number of samples was 150 respondents. Sample was randomly drawn form the population of consumers who visit modern food stalls within the area of a Jambi city in Indonesia. This type of research includes explanatory research. Related 
to the research objectives, the analytical tool used is SEM using PLS (partial least square) software. This SEM measurement with Smart PLS uses the outer model and inner model. Evaluation of the measurement model Or the outer model is done through Confirmatory Factor Analysis (CFA), by testing the validity by looking at the Loading Factor value, Average Variance Extracted (AVE), Communality, and testing the reliability of the model by looking at the Cronbach's alpha.

\section{RESULTS}

An analysis of covariance was conducted to examine the hypotheses. Reliability measurement is used to see whether the questionnaire to be used is reliable or not so that it is feasible to be used as a research questionnaire. The measurement of the reliability of this questionnaire uses the Cronbach's Alpha method. Validity test is used to find out whether the attributes of the questionnaire are able to describe what consumers want. Measurement of validity using the composite reliability method. Final model shown in figure 2 :

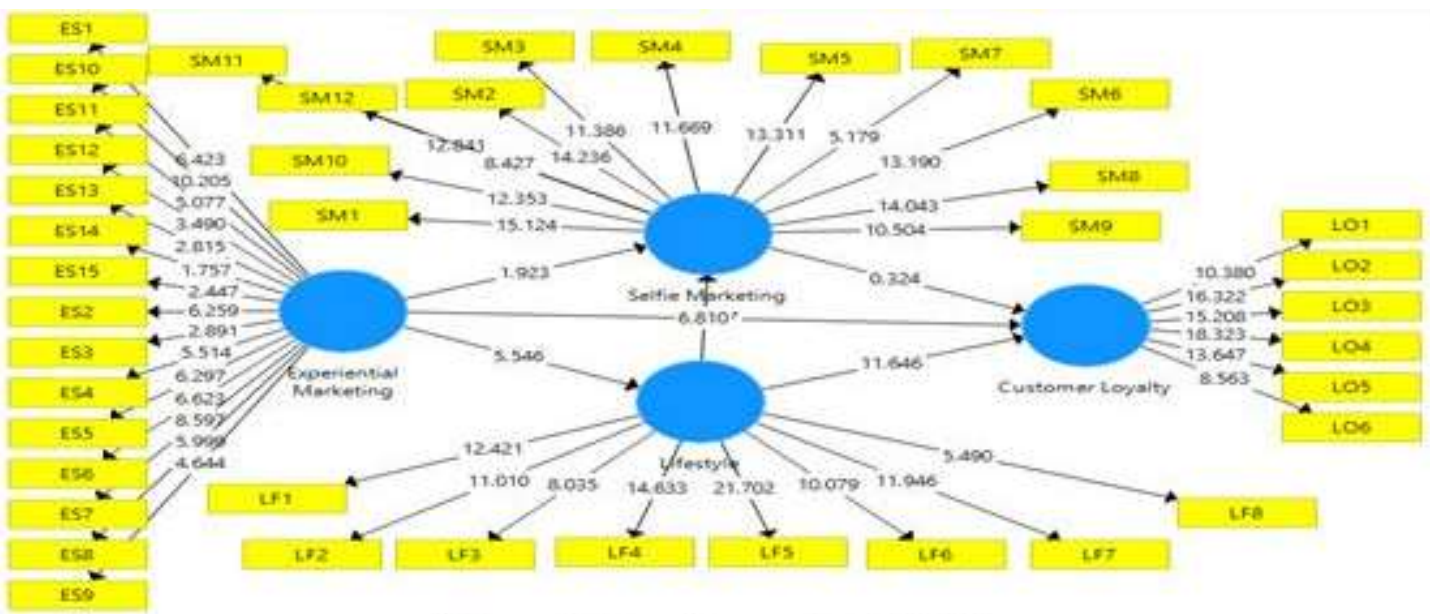

Figure 2. Bootstrapping Model

Hypothesis 1.a predicts the effect of experiential shopping on selfie marketing customer of modern food stalls in Jambi Province. The results show that there is a positive relationship between experiential shopping on selfie marketing and its effect is significant $(\mathrm{t}$ statistic $=1.923$ and $p$-value $=0.00$ ). Next, it is said that the hypothesis $1 . \mathrm{a}$ is proven. People tend to memorize every single memorable experience by capture or take a selfie photograph. Store atmosphere of the modern food stalls is the main reason for people to take picture. This asserts that customer need to have unique, memorable, engaging and personal experiences in the modern food stalls. People who share selfies on their social median such as : Instagram, Facebook or Tweeter may be attempting to express themselves differently based on the experience they had got. Experiences result from stimulations and lead to pleasurable outcomes, and consumers want to repeat these experiences. Berg (2017) stated that the habit of sharing selfie on social media seems to reinforce marketers' commercial messages and contributes to commercial pressure.

Hypothesis 1.b predicts that the dominant experiential shopping variable influencing the selfie marketing variable is store decor with a score of 6,259. The customer mind-set is everything that exist in the minds of customers with respect to a brand; thoughts, feelings, experiences, images, perceptions, beliefs, attitudes and so on. When consumers search for, 
shop for, and consume brands, they are exposed to utilitarian product attributes. However, they are also exposed to various specific brand-related stimuli, such as brand-identifying color. Rodriques (2017) stated that the Store décor can influence the response of customers' emotions in two ways, namely giving pleasure and arousal. The response strongly influences the behavior of consumers. The impressive store décor will attract the attention of visitors to self-portraits, which are then spread through social media with the help of internet technology.

Hypothesis 2 predicts that selfie marketing variables have a significant effect on consumer loyalty. The results show that there is a positive but not significant relationship ( $\mathrm{t}$ statistic $=0.324$ and $\mathrm{p}$-value $=0.746$ ). Thus hypothesis 2 is not proven. According to Ward (2014), self-behavior is able to campaign for something through social media especially if marketing tools cannot be used but this selfie behavior must be done and planned well. Selfie can be a good marketing tool if done properly and real. Three main reasons for running a selfie as a marketing tool include a contest, attachment, and human interest. However, if a person's tendency to self is more to the feeling of self-narcissism, it cannot be a store modern promotion tool so that it has no effect on consumer loyalty. Furthermore brand experiences do not occur only after consumption; they occur whenever there is a direct or indirect interaction with the brand. a brand experience does not need to be surprising; it can be both expected and unexpected (Sahin et al, 2011)

Hypothesis 3.a predicts that experiential shopping and selfie marketing affect consumer loyalty. The results show that there is a positive relationship between the two variables on consumer loyalty ( $\mathrm{t}$ statistical experiential shopping $=0.827 ; \mathrm{p}$ value $=0.409$ and $\mathrm{t}$ statistical selfie marketing $=0.324 ; \mathrm{p}$-value $=0.746$ ). Thus the hypothesis $3 . \mathrm{a}$ is proven. Experience should affect not only past-directed satisfaction judgments but also future directed consumer loyalty. Consumers should be more likely to come and buy a brand again and recommend it to others and less likely to visit an alternate place or brand. According to Donovan and Rossiter in Rodriques (2017) several approaches of consumers to store decor as one of the experiential shopping indicators include : (1) the initial process of approaching or rejecting a place, (2) the process of consumers looking for and exploring the existence of a place, ( 3) the process of reaction between consumers and employees the place and (4) repurchase and buy in large quantities. According to Pine and Gilmore (1999) experiences have an economic value. They also found a significant correlation between experiential value and customer satisfaction. Various other studies have investigated experiential value and found a positive effect of customer experience on desired customer behaviors (satisfaction, loyalty and recommendation) (Bilgihan et al., 2013; Cetin et al, 2014).

\section{KESIMPULAN}

Experiential shopping has a significant effect on selfie marketing on the costumer of modern food since consumer tend to take picture of themselves when they fell comfortable of the atmosphere of the place. The dominant experiential shopping variables that influence the selfie marketing variables are store decor. Experiential shopping and selfie marketing affect consumer loyalty but not significant and experiential shopping have a greater influence on consumer loyalty compared to selfie marketing. 
Funding : This research was funded by Universitas Jambi under regulation of The Institute of Research and Community Service

Competing Interest : The authors declare that this research had competing interest

Acknowledgement : All authors contributed equally to the concept of this study

\section{REFERENCE}

Berg, L (2017). Young consumers in the digital era: The selfie Effect. Int J Consume Stud. 2018;42:379-388. wileyonlinelibrary.com/journal/ijcs

Bilgihan, A., Okumus, F., Nusair, K., \& Bujisic, M. (2013). Online experiences: flow theory, measuring online customer experience in e-commerce and managerial implications for the lodging industry. Information Technology \& Tourism, 1-23.

Bowden, J (2009). Customer Engagement: A Framework for Assessing Customer-Brand Relationships: The Case of the Restaurant Industry. Volume 18, 2009 - Issue 6

Cetin, G., Akova, O., \& Kaya, F (2014). Components of Experiential Value : Case of Hospitality Industry. $10^{\text {th }}$ International Strategic Management Conference. Science direct Procedia - Social and Behavioral Sciences 150 ( 2014 ) $1040-1049$.

Charoensukmongkol, P. (2016). Exploring Personal Characteristic Associated With Selfieliking. Journal of Psychosocial Research On Cyber Space. Vol 10 No.2 (2016).

Cizmeci, F \& Ercan, T, (2015). The Effect of Digital Marketing Communication Tools in The Creation Brand Awareness By Housing Companies. MEGARON 2015;10(2):149-161.

Clark, M. \& Wood, R. (1999), "Consumer loyalty in the restaurant industry", British Food Journal, Vol. 101 No. 4, pp. 317-327. https://doi.org/10.1108/00070709910272196

Fox, A.k.. Bacile, T.J., Nakhata,C. \& Weible, A (2018). Selfie-marketing : Exploring Narcissism and Self-Concept in Visual User-Generated Content On Social Media. Journal of Consumer Marketing 35/1 (2018) 11-21 @ Emerald Publishing Limited.

Farias, S. A., Aguiar, E. C., \& Melo, F. V. S. 2014. Store Atmospherics and Experiential Marketing: A Conceptual Framework and Research Propositions for An Extraordinary

Customer Experience. International Business Research, 7(2): 87-99.

Heung, V, (2007). American theme restaurants: A study of consumer's perceptions of the important attributes in restaurant selection. Journal Asia Pacific Journal of Tourism Research Volume 7, 2002. Taylor \& Francis Online.

Iqani, M \& Schroeder, J ( 2015). Selfie: Digital Self-portraits as Commodity Form and Consumption Practice. Journal Consumption Markets \& Culture. Volume 19, 2016.

Kim. M.S \& Stepchenkova, S (2017). Examining the impact of experiential value on emotions, self-connective attachment, and brand loyalty in Korean family restaurants. Journal of Quality Assurance in Hospitality \& Tourism. ISSN: 1528-008X (Print) 1528-0098 (Online) Journal homepage: http://www.tandfonline.com/loi/wqah20

Kotler, P \& Keller, (2011). Manajemen Pemasaran. Edisi 13 Jilid 1. Erlangga. Jakarta.

Lang, M \& Hooker, N. H.(2013). An Empirical Test of Experiential Shopping in Food Retailing. British Food Journal, vol.115 No5,pp.639-652.

Pine, J \& Gilmore, J. (1999). The Experience Economy: Work is theater and every business stage. Cambridge: Harvard Business Press.

Rodrigues, M.V. (2017). New Trends in Store Atmosphere: An Application to the 
Telecommunication Sector. Dissertation submitted as partial requirement for the conferral of MSc in Marketing.

Sahin, A., Zehirb, C. \& Kitapcib, H (2011). The Effects of Brand Experiences, Trust and Satisfaction on Building Brand Loyalty; An Empirical Research On Global Brands. 7th International Strategic Management Conference. Procedia Social and Behavioral Sciences 24 (2011) 1288-1301. Available online at www.sciencedirect.com

Same, L \& Jorma, L. (2012). Marketing Theory : Experience Marketing and Experiential Marketing. International Scientific Conference "Business and Management. Lithuania.

Schmitt, B. (1999). Experiential Marketing . Journal of Marketing Management. Vol 15 PP 53-67. HTTP : www. Tandfonline.com/lot/rjmmzoo.

Senft, Theresa, \& Baym, N. (2015). What Does the Selfie Say? Investigating a Global Phenomenon. International Journal of Communication 9(2015), Feature 1588-1606 $1932-8036 / 2015$.

Sharma, R \& Visal, S. (2011). Experiential Marketing : A Contemporary Marketing Mix. International Journal Of Management and Strategy. Vol No: II. Issue 3.

Spena, T. R., Caridà, A., Colurcio, M., \& Melia, M. (2012). Store experience and co-creation: the case of the temporary shop. International Journal of Retail \& Distribution Management.

Weichan, J \& Yang, Y, (2016). What Can We Know From Selfies-An Exploratory Study On Selfie And The Implication For Marketers? Global Marketing Conference at Hong Kong 597 2016. http://dx.doi.org/10.15444/GMC2016.05.03.05

Ward, C. (2014). https://www.mycustomer.com/marketing/technology/selfies-as-amarketingtool-inspired-or-insane. 